\title{
Quality of medical information determine the quality of diagnosis code
}

\author{
Warsi Maryati, Indriyati Oktaviano Rahayuningrum, Ani Ismayani Justika \\ Department of Health Science, Universitas Duta Bangsa, Indonesia
}

\begin{tabular}{l}
\hline Article Info \\
\hline Article history: \\
Received Jun 18, 2019 \\
Revised Jul 22, 2019 \\
Accepted Aug 28, 2019 \\
\hline Keywords: \\
Code \\
Diagnosis \\
Information \\
Medical \\
Quality
\end{tabular}

\begin{abstract}
The accuracy of the diagnosis code has implications for future patient care planning, provision of health services and patient care costs. Therefore, this study has analyzed the influence of the quality of medical information on the quality of the diagnosis code which includes the accuracy, consistency, completeness and timeliness in coding the diagnosis of inpatients at Dr. Moewardi hospital. This was an observational analytic study with a sample of 250 medical records taken using stratified random sampling. Data were analyzed by chi square test. High quality of medical information has a better diagnosis code quality (73.80\%) compared to poorly quality of medical information (36.00\%). High quality of medical information has a log odds of 1.54 better in the quality of diagnosis code than poorly quality of medical information $(\mathrm{b}=1.54 ; 95 \% \mathrm{CI}=0.81-2.27, \mathrm{p}<0.001)$.
\end{abstract}

Copyright $@ 2019$ Institute of Advanced Engineering and Science. All rights reserved.

\section{Corresponding Author:}

Warsi Maryati,

Department of Health Science,

Universitas Duta Bangsa,

Road K.H. Samanhudi 93 Sondakan, Laweyan, Surakarta, Central Java Province, Indonesia.

Email: warsi_maryati@udb.ac.id

\section{INTRODUCTION}

The diagnosis code has a very important role in making policies for health care providers. In addition, the diagnosis code is also the basis for determining the cost of health services. Codes of diagnosis that are not qualified will cause harm to hospitals both financially and in policy making [1]. The diagnosis code is very helpful in making detailed bills for proper care costs and reducing the risk of hospital management. Therefore, a diagnosis code audit needs to be done to ensure the quality of the diagnosis code which includes accuracy (validity), consistency (reliability), completeness (completeness) and timeliness in coding (timeliness) [2].

The accuracy of the diagnosis code has implications for future patient care planning, provision of health services and patient care costs [3]. In addition, inconsistent and inappropriate diagnosis codes have major implications for national statistics, analysis of performance and results of payment claims [4]. The inaccuracy of diagnosis codes has implications for very broad financial and policy [5]. Claims for hospital health care costs in casemix-based systems (grouping diagnoses that are homogeneous for the determination of service costs) in the state of Victoria, Australia depend on appropriate, comprehensive and timely clinical codification. About $16 \%$ of the 752 audited cases showed a change in Diagnostic Related Groups (DRGs) and caused significant losses to hospitals, namely AUD 575,300. The main fault diagnosis code accounts for more than $13 \%$ of DRG changes and the absence of an additional diagnosis code of $29 \%$ [6].

Factors that can affect the quality of the diagnosis code include doctors, other medical personnel (nurses) and medical record staff (coders). Doctors and nurses are responsible for the quality of the patient's medical information and the coding is responsible for the quality of the diagnosis code based on medical data [7]. Coder must be able to determine the diagnosis code according to the classification of the 
prevailing diseases in Indonesia, namely the International Statistical Classification of Diseases and Related Health Problems 10th Revision (ICD-10) [2].

The quality of medical information used as a basis for diagnosis coding is strongly influenced by the completeness of filling out the outgoing summary sheet filled by doctors [8]. One of the factors that influence the accuracy of the diagnosis code is medical information [9]. Medical information in question is filling in the diagnosis. Completeness of medical information and the accuracy of medical record documents is very important, if medical information in a medical record document is incomplete, the resulting diagnosis code is inaccurate [10].

The diagnosis code in public hospitals is significantly more appropriate than special hospitals but the number of diagnosis codes with large types of errors in public hospitals [11]. Dr. Moewardi hospital is a public hospital type A Education which has 232 doctors, 721 nurses and 16 coders, each of which has different characteristics. Based on preliminary research, of the 10 medical records documents of inpatients, $40 \%$ of them had poor quality diagnostic codes. The percentage of the inaccuracy of the diagnosis code in Dr. Moewardi amounted to $34.2 \%$ of 380 medical record documents [12]. The percentage inaccuracy of the diagnosis code was higher than the average of other domestic hospitals, which is $31.5 \%$ [9, 13-19] and were still very much higher compared to overseas hospitals which were $12.71 \%[3-6,11]$.

Research on the quality of diagnostic codes had been done a lot before, but only focus on one indicator, namely accuracy. The quality of the diagnosis code is not only assessed based on accuracy, but consistency, completeness and timeliness must also be examined. Therefore, this study has analyzed the influence of the quality of medical information on the quality of the diagnosis code which includes the accuracy, consistency, completeness and timeliness in coding the diagnosis of inpatients at Dr. Moewardi hospital.

\section{RESEARCH METHOD}

This was an observational analytic study with a cross sectional design. The study population was all medical records of inpatients at Dr. Moewardi hospital, Surakarta. The number of samples in the study were 250 medical record documents in the Anggrek, Melati, Mawar, Cendana and Aster wards which were selected by stratified random sampling with 50 documents for each ward. Data was collected using observation tables, medical record quality document analysis sheets, accuracy, consistency, completeness and time accuracy of diagnosis codes analysis sheet, ICD-10 and stopwach. Data were analyzed by univariate and bivariate by Chi-square.

\section{RESULTS AND DISCUSSIONS}

\subsection{Quality of medical information}

The quality of medical information in Dr. Moewardi hospital was mostly well at $164(65.60 \%)$, while the diagnosis code was poorly as $86(34.40 \%)$ as shown in Table 1. Dr. Moewardi hospital uses electronic health records, but doctors and other medical personnel have not been able to use it optimally. Along with the development of electronic health records, the need for inherent nomenclature will force major changes in clinical coding practices. Clinical coders must be experts in technology and information analysis, change their work practices, and become an integral part of the clinical team [20].

Table 1. Quality of medical information in Dr. Moewardi hospital

\begin{tabular}{ccc}
\hline Variabel & $\mathrm{N}$ & $\%$ \\
\hline Quality of medical information & & \\
Poorly & 86 & 34.40 \\
Well & 164 & 65.60 \\
Total & 250 & 100 \\
\hline
\end{tabular}

The quality of medical information is assessed based on three indicators, namely the completeness, accuracy and timeliness of filling in medical record documents. The poor quality of medical information is mostly due to incomplete medical record documents, namely $72(28.80 \%)$. In addition, other factors were inaccurate medical record documents of $16(6.40 \%)$ and not filled in on time as much as $5(2.00 \%)$ as shown in Table 2. Dr. Moewardi hospital conducts Clinical Documentation Improvement (CDI) to improve the quality of medical information in order to support the accuracy of diagnosis and accreditation codes. The CDI is carried out by a team consisting of doctors, paramedics, and medical records. The CDI constraints have not been implemented consistently and continuously. Continuous Quality Improvement (CQI) can be 
used to improve the quality of clinical documentation and coding. Coder needs to implement ways to solve the problem of inadequate clinical documentation and high levels of coding errors, especially in the current casemix-based financing system [21].

Table 2. Quality of medical information indicators

\begin{tabular}{ccccccc}
\hline Quality of medical & \multicolumn{2}{c}{ Poorly } & \multicolumn{2}{c}{ Well } & \multicolumn{2}{c}{ Total } \\
information indicators & $\mathrm{N}$ & $\%$ & $\mathrm{~N}$ & $\%$ & $\mathrm{~N}$ & $\%$ \\
\hline Completeness & 72 & 28.80 & 178 & 71.20 & 250 & 100 \\
Accuracy & 16 & 6.40 & 234 & 93.60 & 250 & 100 \\
Timeliness & 5 & 2.00 & 245 & 98.00 & 250 & 100 \\
\hline
\end{tabular}

\subsection{Quality of the diagnosis code}

Most of the quality of the diagn osis code in Dr. Moewardi hospital was good at $152(60.80 \%)$, while the diagnosis code was not as good as $98(39.20 \%)$ as shown in Table 3. However, the poorer percentage of the diagnosis code was still above the average compared to the average inaccuracy of diagnosis codes in other domestic hospitals, namely $31.50 \%$ [9, 13-19]. In addition, this percentage is still very much higher compared to overseas hospitals, which is $12.71 \%$ [3-6, 11].

Table 3. Quality of diagnosis code in Dr. Moewardi hospital

\begin{tabular}{ccc}
\hline Quality of diagnosis code & $\mathrm{N}$ & $\%$ \\
\hline Poorly & 98 & 39.20 \\
Well & 152 & 60.80 \\
Total & 250 & 100 \\
\hline
\end{tabular}

The quality of the diagnosis code is determined based on indicators of accuracy, consistency, completeness and timeliness of coding. The quality of the diagnosis code that is not good is mostly caused by incomplete diagnosis code, which is $73(29.20 \%)$. The incompleteness of medical information in the summary of patient discharges is the main reason for the inaccuracy of the code. There is a need for adequate education and training for doctors and coders. In addition, doctors and coders need to have constant dialogue if there is a lack of medical information needed for coding [22]. Other factors that caused the quality of the diagnosis code to be poor were the diagnosis code was inconsistent 54 (21.60\%), the diagnosis code was incorrect $31(12.40 \%)$ and the diagnosis code was not coded on time $8(3.20 \%)$ as shown in Table 4 . Code errors because inadequate medical documentation impacts on hospital income. Appropriate claims from hospitals in casemix-based systems in the state of Victoria, Australia that are in accordance with accurate, comprehensive and timely clinical coding [6].

Table 4. Quality of diagnosis code indicators

\begin{tabular}{ccccccc}
\hline Quality of Diagnosis & \multicolumn{2}{c}{ Poorly } & \multicolumn{2}{c}{ Well } & \multicolumn{2}{c}{ Total } \\
Code Indicators & $\mathrm{N}$ & $\%$ & $\mathrm{~N}$ & $\%$ & $\mathrm{~N}$ & $\%$ \\
\hline Accuracy & 31 & 12.40 & 219 & 87.60 & 250 & 100 \\
Consistency & 54 & 21.60 & 196 & 78.40 & 250 & 100 \\
Completeness & 73 & 29.20 & 177 & 70.80 & 250 & 100 \\
Timeliness & 8 & 3.20 & 242 & 96.80 & 250 & 100 \\
\hline
\end{tabular}

\subsection{Correlation between the quality of medical information and the quality of the diagnosis code}

Well quality of medical information has a better diagnosis code quality $(73.80 \%)$ compared to poorly quality of medical information $(36.00 \%)$. Well quality of medical information has a log odds of 4.99 better in the quality of diagnosis code than poorly quality of medical information $(b=4.99,95 \% \mathrm{CI}=2.85-8.75, \mathrm{p}<0.001)$ as shown in Table 5 .

Table 5. Bivariate analysis of the quality of medical information with quality of the diagnosis code

\begin{tabular}{|c|c|c|c|c|c|c|}
\hline \multirow{2}{*}{$\begin{array}{l}\text { Quality of medical } \\
\text { information }\end{array}$} & \multicolumn{2}{|c|}{ Quality of Diagnosis Code } & \multicolumn{4}{|c|}{ CI $(95 \%)$} \\
\hline & Poorly (\%) & Well (\%) & OR & $\begin{array}{l}\text { Lower } \\
\text { limit }\end{array}$ & $\begin{array}{l}\text { Upper } \\
\text { Limit }\end{array}$ & $p$ \\
\hline $\begin{array}{c}\text { Poorly (\%) } \\
\text { Well }(\%)\end{array}$ & $\begin{array}{l}55(64.00 \%) \\
43(26.20 \%)\end{array}$ & $\begin{array}{c}31(36.00 \%) \\
121(73.80 \%)\end{array}$ & 4.99 & 2.85 & 8.75 & $<0.001$ \\
\hline
\end{tabular}

Int. J. Public Health Sci. Vol. 8, No. 3, Sept 2019: 326-331 
Poorly quality of medical information at Dr. Moewardi hospital as many as $86(34.40 \%)$ with the most common causative factor was incomplete medical record. Well quality of medical information also had a better quality diagnosis code $(73.80 \%)$ compared to poorly quality of medical information $(36.00 \%)$. Well quality of medical information had a log odds of 4.99 better in the quality of the diagnosis code than poorly quality of medical information $(b=4.99,95 \% \mathrm{CI}=2.85-8.75, \mathrm{p}<0.001)$. Completeness of writing medical information on each medical record form had an important role in determining the right code through a diagnosis set by the doctor. One of the factors that influence the accuracy of the diagnosis code was medical information [9]. Medical information in question was a diagnosis. Accurate codes were obtained, one of them by paying attention to supporting information or other causes that influence the diagnosis code [23].

The results of this study were also in accordance with the previous research that the medical record documentation was more complete about topography $(\mathrm{p}=0.204)$, subtype $(\mathrm{p}=0.708)$ and etiology $(p<0.001)$ that the disease could affect the accuracy of the diagnosis code [11]. In addition, other research also showed that $50 \%$ of cases of DRGs changes were caused by documentation problems. The main diagnosis code accounted for more than $13 \%$ of DRG changes and the absence of an additional diagnosis code of $29 \%$. The most significant factors underlying the error of diagnosis codes and changes in DRGs were the poorly quality of medical record documentation [6].

Dr. Hospital Moewardi hospital was a teaching hospital, so many medical students and resident doctors practice there. Quality of medical information at Dr. Moewardi hospital was also one of them affected by the documentation errors made by medical students or resident doctors. Doctors had a high workload because in addition to providing services to patients it must also guide medical students or resident doctors. The high workload causes doctors not to have time to check the medical record carried out by its guiding students, so that errors and incomplete medical information (diagnosis) often occur.

The factor of incompatibility of diagnosis because there was no procedure regarding the writing of diagnosis based on ICD-10 [24]. A fixed procedure was a set of instructions or standardized steps for completing a certain routine work process, giving the right and best steps to carry out various activities and functions [25]. Dr. Moewardi hospital should make a fixed procedure about recording medical record documents and diagnosis codification as an effort to improve the quality of the diagnosis code. Anggraini's research proves that one of the variables that was significantly related to performance was work procedure $(\mathrm{p}<0.005)$. The better working procedures for eating will further improve performance [26].

\section{CONCLUSION}

High quality of medical information has a better diagnosis code quality $(73.80 \%)$ compared to poorly quality of medical information (36.00\%). High quality of medical information has a log odds of 1.54 better in the quality of diagnosis code than poorly quality of medical information $(b=1.54,95 \% \mathrm{CI}=0.81-2.27, \mathrm{p}<0.001)$.

\section{ACKNOWLEDGEMENTS} its staff.

On this occasion the author would like to thank the Chancellor of Duta Bangsa University and

\section{REFERENCES}

[1] World Health Organization, "International Satistical Classification of Diseases and Related Health Problems Tenth Revision volume 1, 2 dan 3", Geneva, 2010.

[2] Hatta, G.;, "Health Information Management Guidelines in Health Service Facilities", Universitas Indonesia Press, pp. 53-55, 2013.

[3] Cummings, E.; Maher, R.; Showell, C.M.; Croft, T.; Tolman, J.; Vickers, J.; Stirling, C.; Robinson, A.; Turner, P.; "Hospital coding of Dementia: is it accurate?", Health Information Management Journal, vol. 40, no. 3, pp. 5-11, 2011.

[4] Dalal, S.; Roy, B.; "Reliability of Clinical Coding of Hip Facture Surgery: Implications for Payment by Results?", Inernational Journal Care Injured, vol. 40, no. 1, pp. 738-741, 2009.

[5] Thigpen, J.L.; Pharm; Dillon, C.; Forster, K.B.; Henault, L.; Quinn, E.K.; Tripodis, Y.; Berger, P.B.; Hylek, E.M.; Limdi, N.A.;, "Validity of International Classification of Disease Codes to Identify Ischemic Stroke and Intracranial Hemorrhage among Individuals with Associated Diagnosis of Atrial Fibrillation”, Circulatory Cardiovascular Quaility Outcomes, vol. 8, no. 1, pp. 8-14, 2015.

[6] Cheng, P.; Gilchrist, A.; Robinson, K.M.; Paul, L.; "The Risk and Consequences of Clinical Miscoding due to Inadequate Medical Documentation : A Case Study of the Impact on Health Services Funding". Health Information Management Journal, vol. 38, no. 1, pp. 35-46, 2009. 
[7] Maryati, W.; Murti, B.; Indarto, D.; "Factors Affecting the Quality of Diagnosis Coding and Medical Record at Dr. Moewardi Hospital, Surakarta", Journal of Health Policy and Management, vol. 1, no. 2, pp. 61-70, 2016.

[8] Maryati, W.; "Relationship between Characteristics of Doctors and Completeness of Outgoing Summary Sheet", Jurnal Manajemen Informasi Kesehatan Indonesia, vol. 3, no. 1, pp. 26-35, 2014.

[9] Rohman, H.; Hariyono, W., Rosyidah;, "The Policy for Filling the Main Diagnosis and Accuracy of the Diagnosis Code in Medical Records at PKU Muhammadiyah Hospital in Yogyakarta”, Jurnal KESMAS, vol. 5, no. 2, pp. 162 232, 2011.

[10] Wariyanti, A.S.; "The Relationship Between Completeness of Medical Information with the Accuracy of the Diagnosis Code in Inpatient Medical Records at Karanganyar Regency Hospital in 2013”, Falkultas Ilmu Kesehatan UMS, 2014.

[11] Farzandipour, M.; Sheikhtaheri, A.; Sadoughi, F., "Effective Factors on Accuracy of Principal Diagnosis Coding Based on International Classification of Diseases, the $10^{\text {th }}$ Revision (ICD-10)", International Journal of Information Management, vol. 30, no. 5, pp. 78-84, 2010.

[12] Sudra, R.I.; Pujihastuti, A., "Effects of Writing Dianosis and Knowledge of Medical Record Officers on Medical Terminology on Accuracy of Diagnosis Codes”, Jurnal Manajemen Informasi Kesehatan Indonesia, vol. 4, no. 1, pp. 67-72, 2016.

[13] Arifianto, E.; Kresnowati, L.; Ernawati, D., “Accuracy of the Main Diagnostic Code of Medical Record Documents in Partus Cases with Cesarean Sectio at Panti Wilasa Citarum Hospital”. Jurnal Visi Kesehatan, vol. 10, no. 2, pp. 84-88, 2011.

[14] Rahayu, H.; Ernawati, D.; Kresnowati, L., "Accuracy of Main Diagnosis Code at RM 1 Document of Medical Record of Carmel Room and Characteristics of Inpatient Coding Officer Mardi Rahayu Kudus Hospital, December 2009 Period", Jurnal Visi Kesehatan, vol. 10, no. 1, pp. 1-5, 2011.

[15] Abiyasa, M.T.; Ernawati, D.; dan Kresnowati, L., "Relationship between Specificity of Writing Diagnosis on Accuracy of Code at RM 1 Inpatient Document Bhayangkara Hospital Semarang”. Jurnal Visi Kesehatan, vol.11, no. 2, pp. 99-104, 2012.

[16] Sarwastutik;, "Review of the Accuracy of the Diagnosis Code in Medical Record Documents of Patients Hospitalized with Main Conditions of Typhoid Fever Based on ICD-X in PKU Muhammadiyah Hospital Delanggu", Jurnal Informasi Kesehatan, vol. 3, no. 2, pp. 8-13, 2013.

[17] Pujihastuti, A.; Sudra, R.I.; "Relationship to Completeness of Information with the Accuracy of the Diagnosis and Action Code in the Inpatient Medical Record Document", Jurnal Manajemen Informasi Kesehatan Indonesia, vol. 3, no. 1, pp. 60-64, 2014.

[18] Seruni, F.D.A.; Sugiarsi, S., "Problem Solving SWOT Cycle Accuracy Code Diagnosis of Obstetrics on Entry and Exit (RM 1a) Hospitalized Patients in Dr. Sayidiman Hospital Magetan”, Jurnal Manajemen Informasi Kesehatan Indonesia, vol. 3, no. 2, pp. 5-13, 2015.

[19] Karimah, R.N.; Setiawan, D.; Nurmalia, P.S., "Accuracy Analysis of the Code of Diagnosis of Acute Gastroenteritis Based on Medical Record Documents at Balung Hospital Jember", Journal of Agromedicine and Medical Sciences, vol. 2, no. 2, pp. 12-17, 2016.

[20] Robinson, K.; Shepheard, J., "Predicting the Influence of the Electronic Health Record on Clinical Coding Practice in Hospitals", Health Information Management, vol. 32, no. 3, pp. 102-108, 2004.

[21] Callen, J.; Meehan, J.; Tomornsak, S., "Looking to CQI for improvements in clinical documentation and coding", Health Information Management, vo. 27, no. 1, pp. 7-11, 2017.

[22] Hasan, M.; Meara, R. J.; Bhowmick, B. K., "The Quality of Diagnostic Coding in Cerebrovascular Disease", International Journal for Quality in Health Care, vol. 7, no. 4, pp. 407-410, 2015.

[23] Astuti, R.D; Riyoko; Lena, D., "Accuracy Review of the Main Diagnosis Code of Patients Hospitalized Based on the ICD-10 of the Dahlia Ward in Sukoharjo Hospital, Quarter IV of 2007”. Jurnal Rekam Medis, vol. 2, no. 1, pp. 25-30, 2007.

[24] Sadiyah, A.;, "Accuracy Evaluation of Codefication of Main Diagnosis of Hospitalized Patients Based on ICD-10 at Pertamina Hospital Cirebon", Fakultas MIPA Universitas Gadjah Mada, 2004.

[25] Komisi Akreditasi Rumah Sakit, "Guidelines for Preparing SOPs and Programs in Hospitals”, Jakarta, 2012.

[26] Anggraini, S.S.; "Relationship between Motivation and Performance of Medical Record Officers at the Regional General Hospital Dr. Djasamen Sraagih Pematang Siantar”, Jurnal Informasi Kesehatan Masyarakat, vol. 12, no. 2 , pp. 34-44, 2007.

\section{BIOGRAPHIES OF AUTHORS}

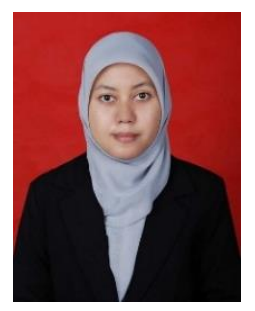

Warsi Maryati, S.K.M., MPH

She is lecturer at Medical Record and Health Information Diploma Program, Health Sciences Faculty, Duta Bangsa University Surakarta

She received her bachelor of public health in Faculty of Public Health, University of Veteran Bangun Nusantara Sukoharjo

Her master of public health was achieved from Sebelas Maret University 


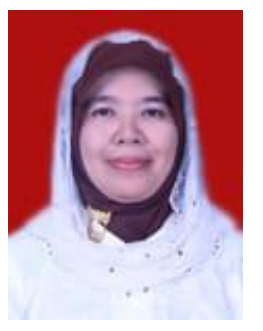

Dr. Indriyati Oktaviano Rahayuningrum, MPH

She is lecturer at Medical Record and Health Information Diploma Program, Health Sciences Faculty, Duta Bangsa University Surakarta

She received her bachelor of medicine in Faculty of Medicine, Sebelas Maret University

Her master of public health was achieved from Sebelas Maret University

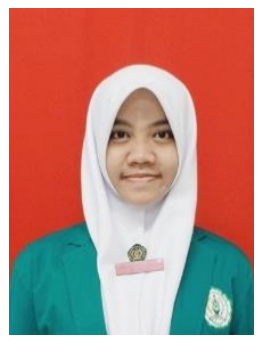

Ani Ismayani Justika

She is student at Medical Record and Health Information Diploma Program, Health Sciences Faculty, Duta Bangsa University Surakarta 